\title{
Peran Dinas Tata Kota Bandar Lampung Dalam Pengendalian Pemanfaatan Tata Ruang
}

\author{
Ati Yuniati
}

Bagian Hukum Administrasi Negara Fakultas Hukum Universitas Lampung Email : ati_yuniati7886@yahoo.com

\begin{abstract}
Abstrak
Tujuan penelitian ini adalah untuk mengetahui Peran Dinas Tata Kota Bandar lampung dalam Pengendalian Pemanfaatan Tata Ruang. Penelitian ini menggunakan pendekatan yuridis normatif dan empiris. Berdasarkan hasil penelitian, Peran Dinas Tata Kota Bandar Lampung dalam pengendalian pemanfaatan tata ruang adalah melaksanakan pengawasan dan penertiban pemanfaatan ruang. Pengendalian pemanfaatan tata ruang yang dilakukan Dinas Tata Kota Bandar Lampung pada saat ini sudah cukup baik dengan melaksanakan kegiatan sebagaimana tugas dan fungsi Dinas Tata Kota yang telah tetapkan dalam Peraturan Walikota Kota Bandar Lampung No. 17 Tahun 2008 tentang Tugas, Fungsi dan Tata Kerja Dinas Tata Kota Bandar Lampung.
\end{abstract}

Kata kunci : peran, pengendalian, pemanfaatan, tata ruang.

\begin{abstract}
The purpose of this study was to determine the role of city planning office of Bandar lampung in Spatial Utilization Control. This study uses empirical and normative juridical approach. Based on this research, the role of city planning office of Bandar lampung in controlling the spatial utilization is to supervise and control the utilization of space. Control of spatial utilization conducted city planning office of Bandar lampung at this time is good enough to carry out the duties and functions of city planning office as has set in the Bandar Lampung Mayor Regulation No. 17 of 2008 on Duties, Functions and Administration of the City Planning Office Bandar Lampung.
\end{abstract}

Key words: role, control, utilization, spatial.

\section{Latar Belakang}

Sebagai kota yang menuju kota besar, Bandar Lampung menjadi pusat kegiatan perekonomian di daerah Lampung. Sebagian besar penduduknya bergerak dalam bidang jasa, industri, dan perdagangan. Untuk mewujudkan efisiensi pemanfaatan ruang sebagai tempat berlangsungnya kegiatan-kegiatan ekonomi dan sosial budaya, maka kawasan perkotaan perlu dikelola secara optimal melalui penataan 
ruang. Sebagai salah satu proses kegiatan penataan ruang, penyusunan rencana tata ruang kawasan perkotaan perlu diselenggarakan sebagai bagian yang tidak terpisahkan dari Rencana Tata Ruang Wilayah.

Berdasarkan ketentuan Pasal 3 Undang-Undang No. 26 Tahun 2007 tentang Penataan Ruang menyatakan bahwa penyelenggaraan penataan ruang bertujuan untuk mewujudkan ruang wilayah nasional yang aman, nyaman, produktif dan berkelanjutan berlandaskan wawasan nusantara dan ketahanan nasional. Untuk dapat menjaga konsistensi dari pemanfaatan ruang terhadap rencana tata ruang wilayah, setiap pemerintah kota memerlukan upaya pemantauan terhadap pemanfaatan ruang yang berjalan serta mengevaluasi kesesuaian dari pemanfaatan ruang terhadap rencana tata ruang wilayahnya.

Pemerintah kota saat ini diberi kewenangan dalam penyusunan rencana tata ruang wilayah kota. Permasalahan dalam tata ruang yang sekarang dialami oleh banyak kota di Indonesia antara lain penggunaan ruang yang tidak teratur dan tidak sesuai dengan Rencana Tata Ruang Wilayah (RTRW) serta penggunaan ruang tanpa memperhatikan dampak negatif yang disebabkan terhadap keadaan lingkungan. Hal ini mengakibatkan masalah seperti kesemrawutan tata ruang wilayah hingga bencana alam yang diakibatkan oleh kesalahan dalam penggunaan ruang karena lebih berorientasi untuk mencari keuntungan pribadi atau korporasi tanpa menghiraukan akibat dari penyimpangan penggunaan ruang tersebut. Oleh karena itu, ruang perlu ditata agar dapat memelihara keseimbangan lingkungan dan memberikan dukungan yang nyaman terhadap manusia serta mahluk hidup lainnya dalam melakukan kegiatan dan memelihara kelangsungan hidupnya secara optimal.

Semakin pesatnya perkembangan Kota Bandar Lampung memerlukan pengarahan, penelitian dan perencanaan. Untuk menciptakan tertib pembangunan dan pengembangan kota sebagai unsur pendorong Pembangunan Nasional dan sesuai pula dengan kebijakan Pemerintah untuk melaksanakan pembangunan kota secara terpadu, pemanfaatan ruang kota secara lestari, optimal, seimbang, serasi sangat diperlukan.

Dalam rangka untuk mengembangkan Kota Bandar Lampung sesuai karakteristik dan fungsinya serta memenuhi ketentuan mengenai pemanfaatan ruang, maka perlu diadakannya pengendalian pemanfaatan tata ruang yang tepat. Berdasarkan uraian tersebut, bagaimana Peran Dinas Tata Kota Bandar lampung dalam Pengendalian Pemanfaatan Tata Ruang?

\section{Metode Penelitian}

Penelitian ini menggunakan pendekatan secara yuridis normatif dan pendekatan secara empiris. Sumber data dalam penelitian yaitu sumber data primer dan sumber data skunder. Bahan hukum yang digunakan yaitu bahan hukum primer, bahan hukum skunder dan bahan hukum tersier. Analisis data dilakukan secara kualitatif. 
Kemudian dilakukan interpretasi data dan kemudian dilakukan pembahasan yang akan menuju kepada kesimpulan terhadap permasalahan yang diteliti.

\section{Peran Dinas Tata Kota Dalam Pengendalian Pemanfaatan Ruang}

Pengendalian pemanfaatan ruang adalah upaya untuk mewujudkan tertib tata ruang. Rencana Umum Tata Ruang Kota (RUTRK) Bandar Lampung disusun untuk dimensi waktu perencanaan 10 tahun. Pada dasarnya RUTRK merupakan rencana pengembangan daerah kota melalui pendekatan tata ruang. Produknya adalah arahan pembangunan yang mempunyai implikasi penataan ruang pada tingkat kota. Dalam kaitan ini maka selain aspek penyusunannya sendiri, maka aspek pelaksanaannya juga menjadi bagian tak terpisahkan yang perlu mendapat perhatian.

Berdasarkan bagan I, dapat diketahui bahwa pengendalian pemanfaatan ruang dilakukan oleh Dinas Tata Kota Bandar Lampung yaitu pengawasan pemanfaatan ruang dan penertiban penataan ruang. Pengawasan pemanfaatan ruang dilakukan dengan pembuatan laporan perubahan pemanfaatan ruang, pemantauan penyimpangan pemanfaatan ruang dan evaluasi rencana pemanfaatan ruang. Sedangkan penertiban pemanfaatan ruang dilakukan dengan pemberian sanksi administratif, sanksi perdata dan sanksi pidana.

Pengendalian pemanfaatan ruang adalah untuk tercapainya konsistensi pemanfatan ruang dengan rencana tata ruang yang telah ditetapkan.
Untuk melaksanakan pengendalian tersebut, Dinas Tata Kota Bandar Lampung mempunyai wewenang melakukan pengawasan dan penertiban. Oleh karena itu, Dinas Tata Kota Bandar Lampung berperan dalam melakukan pengawasan dan penertiban terhadap pemanfaatan ruang yang tidak sesuai dengan rencana tata ruang Kota Bandar Lampung yang telah diatur dalam Peraturan Daerah Kota Bandar Lampung No. 4 Tahun 2004 tentang Rencana Tata Ruang Wilayah Kota Bandar Lampung Tahun 2005 Sampai Dengan Tahun 2015 dan juga Undang-Undang No. 26 Tahun 2007 tentang Penataan Ruang serta peraturan pelaksana lainnya seperti Peraturan Pemerintah dan Peraturan Menteri yang mengatur tentang penataan ruang.

Dalam melaksanakan pengendalian pemanfaatan ruang di Kota Bandar Lampung dilaksanakan oleh Bidang Pengawasan dan Pengendalian Dinas Tata Kota Bandar Lampung. Dalam pengendalian pemanfaatan ruang, Dinas Tata Kota berperan dalam mengawasi dan mengendalikan pemanfaatan ruang kota berdasarkan Rencana Tata Ruang Kota, melakukan identifikasi dan inventarisasi terhadap bangunan dan tempat-tempat usaha yang belum memiliki izin. Dinas Tata Kota untuk mengendalikan pemanfaatan ruang dengan mengeluarkan surat teguran pelanggaran pemanfaatan ruang kota terhadap pihak pemilik bangunan dan tempat-tempat usaha dan membuat laporan pengawasan pemanfaatan ruang kota. 


\section{Gambar. 1 \\ Lingkup Pengertian Pengendalian Pemanfaatan Ruang}

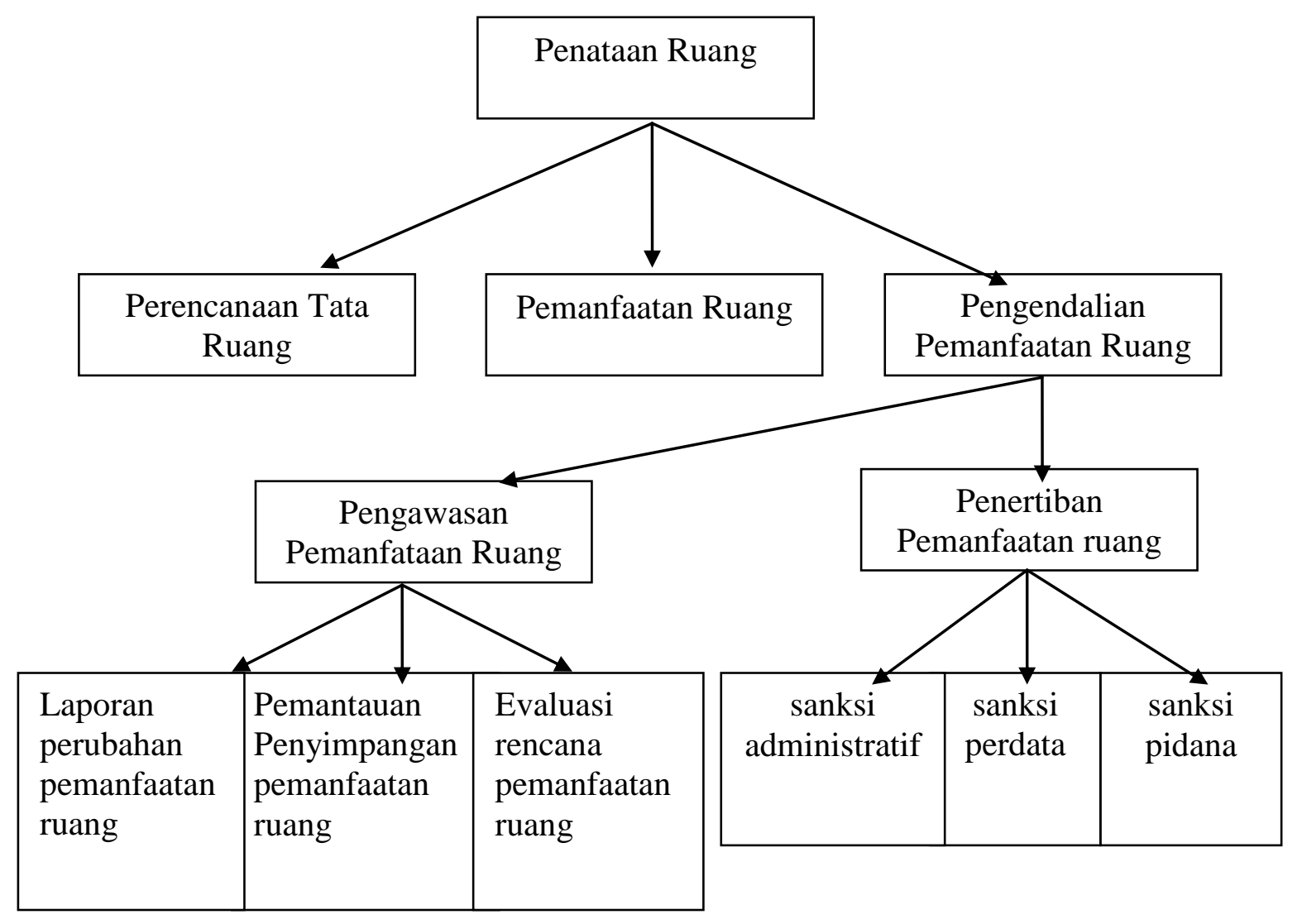

Penyelenggaraan pengendalian pemanfaatan ruang dilakukan melalui kegiatan pengawasan, penertiban, dan mekanisme perizinan (di tingkat kecamatan/kota). Penertiban adalah tindakan menertibkan yang dilakukan melalui pemeriksaan dan penyelidikan atas semua pelanggaran atau kejahatan yang dilakukan terhadap pemanfaatan ruang yang tidak sesuai dengan rencana tata ruang. Pengendalian perkembangan atau pembangunan dengan dua cara di atas dilakukan terutama sekali dalam kaitannya dengan rencana kawasan budidaya. Untuk kawasan lindung, ketentuan yang ada relatif ketat memberikan pembatasan terhadap segala bentuk pemanfaatan ruang yang bersifat budidaya.

Pengendalian pemanfaatan ruang dilakukan oleh Dinas Tata Kota dengan cara pengawasan dan penertiban. Pengawasan dilakukan dengan mengawasi kesesuaian pemanfaatan ruang dengan fungsi ruang yang telah ditetapkan dalam rencana tata ruang. Pengawasan ini dilakukan dalam bentuk:

a. Pelaporan, yaitu usaha atau kegiatan memberikan informasi secara obyektif mengenai pemanfaatan ruang, baik yang 
sesuai maupun yang tidak sesuai dengan rencana tata ruang.

b. Pemantauan, yaitu usaha atau kegiatan mengamati, mengawasi dan memeriksa dengan cermat perubahan kualitas tata ruang dan lingkungan yang tidak sesuai dengan rencana tata ruang.

c. Evaluasi, yaitu usaha atau kegiatan untuk menilai kemajuan kegiatan pemanfaatan ruang secara keseluruhan setelah terlebih dahulu dilakukan kegiatan pelaporan dan pemantauan untuk mencapai tujuan rencana tata ruang.

Tahapan proses pengawasan meliputi pelaporan, pemantauan dan evaluasi. Pengawasan penataan ruang adalah upaya agar penyelenggaraan penataan ruang dapat diwujudkan sesuai dengan ketentuan peraturan perundang-undangan.

Berdasarkan tugas dan fungsinya, kelembagaan yang terlibat dalam proses ini adalah instansi-instansi teknis di tingkat kabupaten/kota dan provinsi, aparat pemerintahan di tingkat yang lebih kecil (kecamatan, kelurahan/desa). Lembaga Swadaya Masyarakat (LSM), masyarakat dan lembaga swasta lain yang mempunyai kepentingan terhadap pemanfaatan ruang. Semua mempunyai wewenang yang yang sama dalam melaporkan setiap tindakan penyimpangan pemanfaatan ruang ruang, yang dilakukan secara berjenjang dari lingkup terkecil hingga lingkup terbesar.

Pemanfaatan yang sesuai dengan rencana tata ruang dipilah menjadi 3 (tiga) yaitu yang tidak menimbulkan masalah, yang menimbulkan masalah kecil, dan yang menimbulkan masalah besar. Dari ketiga kriteria tersebut, akan dijadikan masukan sebagai peninjauan kembali RUTRK Kota Bandar Lampung. Kemudian dari pemanfaatan yang tidak sesuai dengan RUTRK dipilah menjadi 2 (dua), berdampak kecil dan besar, dan nantinya akan ditarik kesimpulannya sebagai rekomendasi Gubernur dan Walikota Bandar Lampung untuk dilakukan penertiban dari penyimpangan yang ada.

Pengawasan pemanfaatan ruang adalah usaha untuk menjaga kesesuaian pemanfaatan ruang dengan fungsi ruang yang ditetapkan dalam rencana tata ruang berupa pengumpulan data dengan melalui proses visualisasi, pengawasan dan monitoring untuk kemudian dievaluasi dari setiap pemanfaatan ruang/lahan yang terjadi.

Pengendalian pemanfaatan ruang tersebut dilakukan pula melalui:

1. Penetapan pengaturan zonasi yang disusun berdasarkan rencana rinci tata ruang untuk setiap zona pemanfaatan ruang. Peraturan zonasi ditetapkan dengan Peraturan daerah.

2. Perizinan pemanfaatan ruang diatur oleh pemerintah daerah menurut kewenangannya sesuai dengan ketentuan peraturan perundang-undangan.

3. Dalam pelaksanaan pemanfaatan ruang agar pemanfaatan ruang sesuai dengan rencana tata ruang wilayah dapat diberikan insentif dan/atau disinsentif oleh pemerintah daerah. Insentif merupakan upaya untuk memberikan imbalan terhadap pelaksanaan kegiatan yang sejalan dengan rencana tata 
ruang.

Disinsentif merupakan upaya untuk mencegah, membatasi pertumbuhan, atau mengurangi kegiatan yang tidak sejalan dengan rencana tata ruang. Insentif dan disinsentif diberikan dengan tetap menghormati hak masyarakat.

4. Pengenaan sanksi merupakan tindakan penertiban yang dilakukan terhadap pemanfaatan ruang yang tidak sesuai dengan rencana tata ruang dan peraturan zonasi. Pengenaan sanksi berupa sanksi administratif, sanksi perdata dan sanksi pidana. Perizinan pemanfaatan ruang dimaksudkan sebagai upaya penertiban pemanfaatan ruang sehingga setiap pemanfaatan ruang harus dilakukan sesuai dengan rencana tata ruang. Pemanfaatan ruang yang tidak sesuai dengan rencana tata ruang, baik yang dilengkapi dengan izin maupun yang tidak memiliki izin, dikenai sanksi administratif, sanksi pidana penjara, dan/atau sanksi pidana denda.

Dalam hal penetapan pengaturan zonasi, Dinas Tata Kota Bandar Lampung mempunyai peran melakukan peraturan zonasi yang disusun berdasarkan rencana rinci tata ruang untuk setiap zona pemanfaatan ruang. Sedangkan untuk pemberian insentif dan disinsentif Dinas Tata Kota Bandar Lampung tidak mempunyai kewenangan memberikan insentif dan disinsentif tersebut. Sampai tahun 2011, Dinas Tata Kota Bandar Lampung belum pernah memberikan insentif dan disinsentif. Insentif dan disinsentif merupakan kewenangan dari Badan Penanaman Modal dan Perizinan
Kota Bandar Lampung berdasarkan Peraturan Walikota Bandar Lampung Nomor 37 Tahun 2008.

Pada tahun 2011 Dinas Tata Kota telah melakukan kegiatan pengawasan dan pengendalian bangunan gedung dan tempat usaha. Kegiatan pengawasan ini dilakukan pada setiap tahunnya dengan rincian waktu yang disesuaikan. Bentuk pengendaliannya adalah dengan memberikan surat peringatan terhadap pemilik bangunan atau gedung yang menyalahi aturan tata ruang Kota Bandar Lampung. Peringatan ini dilakukan secara tertulis dan secara langsung yaitu sebanyak tiga kali untuk memperbaiki bangunan atau gedung tersebut sesuai dengan tata ruang Kota Bandar Lampung. Apabila pemilik bangunan atau gedung tidak mengindahkan peringatan ini, Dinas Tata Kota membentuk tim yang terdiri dari Kepolisian, Satpol PP, TNI dan BPMP Kota Bandar Lampung untuk melakukan penertiban terhadap bangunan atau gedung tersebut.

\section{Penutup}

Berdasarkan uraian di atas, dapat diketahui Peran Dinas Tata Kota Bandar Lampung dalam pengendalian pemafaatan tata ruang adalah melaksanakan pengawasan yang terdiri pembuatan laporan perubahan pemanfaatan ruang, pemantauan penyimpangan pemanfaatan ruang dan evaluasi rencana pemanfaatan ruang. Sedangkan penertiban pemanfaatan ruang dilakukan dengan pemberian sanksi administratif, sanksi perdata dan sanksi pidana. 
Pengendalian pemanfaatan tata ruang yang dilakukan Dinas Tata Kota Bandar Lampung pada saat ini sudah cukup baik dengan melaksanakan kegiatan sebagaimana tugas dan fungsi Dinas Tata Kota yang telah tetapkan dalam Peraturan Walikota Kota Bandar Lampung No. 17 Tahun 2008 tentang Tugas, Fungsi dan Tata Kerja Dinas Tata Kota Bandar Lampung.

\section{DAFTAR PUSTAKA}

Hermit, Herman. 2008. Pembahasan Undang-Undang Penataan Ruang. Mandar Maju, Bandung.

Hadjon, Philipus M. 1987. Perlindungan Hukum Bagi Rakyat di Indonesia, Bina Ilmu, Surabaya.

2005. Pengantar Hukum Administrasi Indonesia. Gadjah Mada University Press, Yogyakarta.

Muhammad, Abdulkadir. 2004. Metode Penelitian Hukum. PT Citra Aditya Bakti. Bandung.

Nurmandi, Acmad.

1999. Manajemen Perkotaan Aktor, Organisasi dan Pengelolaan Daerah Perkotaan di Indonesia. Lingkaran Bangsa, Yogyakarta.

Ridwan, Juniarso. 2009. Hukum Administrasi Negara dan Kebijakan Pelayanan Publik. Nuansa, Bandung.

Soekamto, Soejono. 1982. Sosiologi Suatu Pengantar, Rajawali Press, Jakarta.
Sudarsono, 2005. Kamus Hukum, Rineka Cipta, Jakarta.

Sunggono, Bambang, 2001. Metodologi Penelitian Hukum, PT. Raja Grafindo Persada, Jakarta.

Syahrin, Alvi. 2003. Pengaturan Hukum dan Kebijakan Pembangunan Perumahan dan Pemukiman Berkelanjutan. Pustaka Bangsa, Medan.

Indonesia, Undang-Undang No. 26 Tahun 2007 tentang Penataan Ruang , Peraturan Menteri Dalam Negeri No. 28 Tahun 2008 tentang Tata Cara Evaluasi Rancangan Peraturan Daerah , Peraturan Menteri Dalam Negeri No. 50 Tahun 2009 tentang Pedoman Koordinasi Penataan Ruang Daerah

, Peraturan Daerah Kota Bandar Lampung No. 4 Tahun 2004 tentang Rencana Tata Ruang Wilayah Kota Bandar Lampung Tahun 2005 Sampai Dengan Tahun 2015 , Peraturan Walikota Bandar Lampung No. 17 Tahun 2008 tentang Tugas, Fungsi dan Tata Kerja Dinas Tata Kota Bandar Lampung 